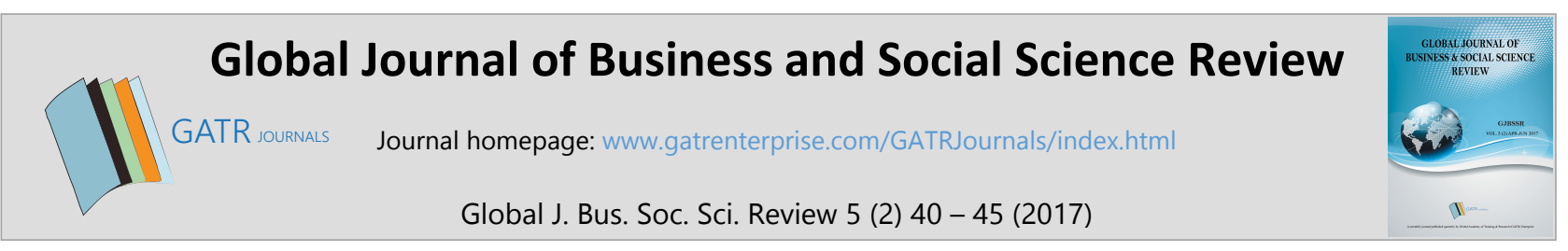

\title{
The Impact of Macro Economy on Stock Price Index: An Empirical Study of Five ASEAN Countries
}

\author{
Embun Prowanta ${ }^{1 *}$, Moeljadi ${ }^{2}$, Sumiati $^{3}$ and Kusuma Ratnawati ${ }^{4}$ \\ ${ }^{1}$ Doctoral Student of Management, Faculty of Economics and Business, University of Brawijaya, 65142, Malang, Indonesia \\ ${ }^{1}$ Faculty of Economics and Business, Perbanas Institute, 12940, Jakarta, Indonesia \\ ${ }^{2,3,4}$ Faculty of Economics and Business, University of Brawijaya, 65142, Malang, Indonesia
}

\section{ABSTRACT}

Objective - The objective of the study is to empirically investigate the relationship between macroeconomic variables as Gross Domestic Product (GDP), inflation, interest rates, exchange rates, foreign exchange reserves, current accounts and export-import towards the stock price index.

Methodology/Technique - The data used is monthly data for macroeconomic and the stock price index of five ASEAN countries including Indonesia, Malaysia, Singapore, Thailand and the Philippines from 2006 to 2015. The analysis uses a regression estimation of panel data and a series of chow tests i.e. the Hausman test and the LM test as the selection process, with the aim of determining the macroeconomic variables that could significantly affect the stock price index of five ASEAN countries.

Findings - The result show that of the seven macroeconomic variables affecting the stock price index, only four macroeconomic variables showed a significant effect. These are GDP, interest rates, exchange rates, and inflation. Meanwhile, three other variables (foreign exchange reserves, current accounts and export-import) did not show a significant effect.

Novelty - The study looked at the effect of deregulation on stock markets, focusing on variables that significantly influence the stock price index.

Type of Paper: Empirical.

Keywords: Stock Price Index; Macro Economics; Five ASEAN Countries.

JEL Classification: E31, G14, G15.

\section{Introduction}

The capital market plays an important role in shaping the economic and political development of a country. Drastic decline in stock prices in a short time and sustained fluctuating stock prices in the capital market, is likely to encourage a financial crisis and push the economy into recession. Most of the world's major capital markets were strongly influenced by the global economic crisis (Oseni \& Nwosa, 2011). Kurihara (2006) showed that gross domestic product, exchange rates, interest rates, and inflation rate have a relationship and influence on bullish market conditions in the capital markets of a country.

\footnotetext{
* Paper Info: Revised: December 13, 2016

Accepted: April 24, 2017

* Corresponding author:

E-mail: embuncfp@gmail.com

Affiliation: Faculty of Economics and Business, University of Brawijaya, Indonesia
} 
As a form of elaboration of macroeconomic variables above, Fama (1981) showed that the rate of GDP growth has a strong positive contemporary relationship with the return of a stock price index. In addition, research conducted by Nishat and Shaheen (2004), Naka, Mukherjee, and Tufte (1998), concluded that GDP was the largest positive determinant of stock prices in emerging markets, and there was a significant relationship between GDP and stock prices.

Additionally, there is significant influence between inflation and stock market. Research conducted by Gültekin, M. and Gultekin, N. (1983), Fama (1981) and Saunders and Tress (1981) shows that the rate of nominal return on equity indices and inflation related significantly negatively with the predominantly negative regression coefficient.

In a related study, Elite Forex Signal (2013) demonstrate the relationship between foreign exchange reserves and the stock market. Ray (2012) states that foreign exchange reserves have a positive relationship to stock market capitalization although the research of Elite Forex Signal (2013) shows that this relationship is not significant. According to Kwon and Shin (1999) and Kandir (2008) there is a positive correlation between the performance of the stock market and lucrative export due to the excess volume that occurrs on corporate transactions within a country.

Research conducted by Kurihara (2006), Ologunde, Elumilade, and Asaolu (2007) showed that the level of stock market capitalization is significantly influenced by the macroeconomic environment, including current accounts and found that the prevailing current account had a positive influence on the level of stock market capitalization.

\section{Literature Review}

The literature surrounding understanding and conducting research about stock markets and economic variables uncovers a wide variety of models such as the research conducted by Joseph Tagne Talla (2013) in his study entitled "Impact of Macroeconomic Variables on the Stock Market Prices of the Stockholm Stock Exchange (OMXS30)". By using the linear regression test, Talla showed that high inflation and the depreciation of the Swedish Krona against the Euro significantly affected stock price movement in the Stockholm Stock Exchange (OMXS30). Inflation and exchange rates also negatively related to stock price but not significantly associated between interest rates and stock prices.

In relation to the stock markets of ASEAN countries, recent research conducted by Auzairy et al. (2011) entitled "Stock Market Deregulation, Variables Macroeconomic and Stock Market Performances" is important. The purpose of this paper is to explore the effects of deregulation of the stock market on the stock market of the ASEAN-3; Malaysia, Thailand and Indonesia. Subsequent consequences of the deregulation of the stock market is analyzed with and without the inclusion of macroeconomic variables. Thus, this study also explores the effects of macroeconomic factors such as exchange rates, interest rates, oil prices and market liquidity to stock market performance. The empirical findings support two conclusions; first, the stock market deregulation policies that were implemented during and after 1997 are not significantly effective and secondly, macroeconomic variables have a significant impact on the performance of the stock market.

The objective of this study is to empirically investigate the relationship between macroeconomic variables as Gross Domestic Product (GDP), inflation, interest rates, exchange rates, foreign exchange reserves, current accounts and export-import, towards the stock price index. The data used is monthly data for macroeconomic and stock price index of five ASEAN countries including Indonesia, Malaysia, Singapore, Thailand and the Philippines from 2006 to 2015. 


\section{Methodology}

\subsection{Data and Variables}

The population used in this study is the macro data from five ASEAN countries; Indonesia, Malaysia, Singapore, Philippines and Thailand. The samples used in this study use saturated sampling techniques so that all of the population sample is used in the study.

This type of data extracted from this research is secondary data in the form and type of explanatory research. In determining monthly data from 2006 to 2015, the eight variables used consisted of seven independent variables and one dependent variable. The independent variables in this study were Gross Domestic Product (GDP) X1, inflation (INF) X2, Exchange Rate (EXCH) X3, Interest Rate (INT) X4, Foreign Exchange Reserves (CD) X5, Current Account (CA) X6 and Export-Import (EXIM) X7. The dependent variable in this study is the stock price index of the five ASEAN countries (Y).

\subsection{Specification Model}

This study uses data panel analysis techniques consisting of several variables such as the cross section but it also has elements of time such as time series data. Data processing tools used in this study included eviews. There are three techniques that can be used in the estimation technique of the panel data regression model (Widarjono, 2010 p.9):

a) Common effect model using the least squares method or the so-called OLS (Ordinary Least Square) that incorporates all the usual data time series with cross section by the following equation:

$$
Y_{i t}=\alpha+\beta X_{i t}+\varepsilon_{i t}
$$

Where: $\mathrm{i}=1,2 \ldots, \mathrm{N} ; \mathrm{t}=1,2, \ldots . \mathrm{T}$,

b) Fixed Effect Model. In this approach, the data panel model has an intercept which may vary for each individual and time, where each unit cross section is fixed in a time series. The mathematical model of panel data using a fixed effect approach is as follows:

$$
\begin{gathered}
Y_{i t}=\alpha+\beta X_{1 t}+\gamma_{2} W_{2 t}+\gamma_{3} W_{3 t}+\cdots+\gamma_{N} W_{N T}+\sigma_{2} Z_{i t}+ \\
\sigma_{3} Z_{i 3}+\ldots+\sigma_{T} Z_{i T}+\varepsilon_{i t}
\end{gathered}
$$

c) Random Effect Model by estimating panel data where disturbance variables may be interconnected across time and between individuals. This model has a different intercept random effect that was accommodated by the error terms of each sample. The random effect model uses the following equation:

$$
Y_{i t}=\alpha+\beta X_{i t}+\varepsilon_{i t} ; \quad \varepsilon_{i t}=u_{i}+v_{t}+w_{i t}
$$

There are many studies that discuss the effect of macroeconomic variables on stock price index using results extracted from the use of a multiple regression model. This research contributes novelty as it uses macroeconomic variables such as GDP, inflation, interest rates, and the exchange rate of the five ASEAN countries in a comprehensive manner, selecting the variable that is considered a leading indicator of the movement stock price index with a panel regression, thus obtaining a multiple linear regression model (Fahrmeir et al, 2013). 


\section{Result and Discussion}

The selection process conducted on the 7 (seven) independent variables is conducted based on the relevance and significance of the influence of these variables on the dependent variable (Stock Price Index for ASEAN:5 countries).

Table 1. Common Effect Result

\begin{tabular}{|c|c|c|c|c|}
\hline Variable & Coefficient & Std. Error & t-Statistic & Prob. \\
\hline CA & 2.086859 & 10.18967 & 0.204802 & 0.8386 \\
\hline CD & 3.618199 & 3.680615 & 0.983042 & 0.3306 \\
\hline EXCH & 0.300191 & 0.071187 & 4.216919 & 0.0001 \\
\hline EXIM & -3.658265 & 7.413211 & -0.493479 & 0.6240 \\
\hline GDP & 92.86684 & 12.73938 & 7.289746 & 0.0000 \\
\hline INF & -8.678949 & 33.92937 & -0.255795 & 0.7992 \\
\hline INT & -25224.01 & 7131.359 & -3.537054 & 0.0009 \\
\hline C & 1862.169 & 553.8602 & 3.362164 & 0.0015 \\
\hline \multicolumn{5}{|c|}{ Weighted Statistics } \\
\hline R-squared & 0.637978 & Mean dependent var & 3870.636 \\
\hline Adjusted R-squared & 0.584060 & S.D. dependent var & 2974.669 \\
\hline S.E. of regression & 1241.845 & Sum squared resid & 72482468 \\
\hline F-statistic & 11.83234 & Durbin-Watson stat & 0.559352 \\
\hline Prob(F-statistic) & 0.000000 & \multicolumn{1}{|l|}{} \\
\hline \multicolumn{5}{|c|}{ Unweighted Statistics } \\
\hline R-squared & -0.005527 & Mean dependent var & 2636.815 \\
\hline Sum squared resid & 1.42 E+ 08 & Durbin-Watson stat & 0.145735 \\
\hline Source Data Procssed
\end{tabular}

Source: Data Processed

From the above calculation, through the test of common effect, it can be concluded that the GDP (GDP), Exchange Rate (EXCH) and Interest Rate (INT) variables have a significant influence on the stock price index of the five ASEAN countries. As each country has a smaller probability value of alpha (0.05), the variable inflation, foreign exchange reserves (CD), Current account (CA) and the Export-Import (EXIM), with effect common test, produces no significant effect on the composite stock index of the five ASEAN countries.

Table 2. Fixed Effect Result

\begin{tabular}{|c|c|c|c|c|}
\hline \multirow{2}{*}{$\frac{\text { Variable }}{\mathrm{CA}}$} & \multicolumn{2}{|c|}{ Coefficient Std. Error } & \multirow{2}{*}{$\begin{array}{l}\text { t-Statistic } \\
-1.245081 \\
\end{array}$} & \multirow{2}{*}{$\begin{array}{l}\text { Prob. } \\
0.2198\end{array}$} \\
\hline & -5.819316 & 4.673846 & & \\
\hline $\mathrm{CD}$ & -13078.76 & 8171.404 & -1.600553 & 0.1168 \\
\hline EXCH & 0.280647 & 0.063361 & 4.429358 & 0.0001 \\
\hline EXIM & 1.013441 & 5.135014 & 0.197359 & 0.8445 \\
\hline GDP & 81.30650 & 20.86589 & 3.896622 & 0.0003 \\
\hline INF & -45.79829 & 21.30728 & -2.149420 & 0.0373 \\
\hline INT & 6.475261 & 2.693422 & 2.404102 & 0.0206 \\
\hline $\mathrm{C}$ & 1705.512 & 384.9743 & 4.430197 & 0.0001 \\
\hline \multicolumn{5}{|c|}{ Cross-section fixed (dummy variables) } \\
\hline \multicolumn{5}{|c|}{ Weighted Statistics } \\
\hline R-squared & 0.906943 & \multicolumn{2}{|c|}{ Mean dependent var } & 3785.532 \\
\hline Adjusted R-squared & $\begin{array}{ll}\mathrm{d} & 0.883138 \\
\end{array}$ & \multicolumn{2}{|c|}{ S.D. dependent var } & 2219.450 \\
\hline 1 & 681.2737 & \multicolumn{2}{|c|}{ Sum squared resid } & 19957753 \\
\hline F-statistic & 38.09846 & \multicolumn{2}{|c|}{ Durbin-Watson stat } & 1.569418 \\
\hline Prob(F-statistic) & 0.000000 & & & \\
\hline \multicolumn{5}{|c|}{ Unweighted Statistics } \\
\hline R-squared & 0.815446 & \multirow{2}{*}{\multicolumn{2}{|c|}{ Mean dependent var }} & 2636.815 \\
\hline Sum squared resid & 26021608 & & & 0.688926 \\
\hline
\end{tabular}


From the calculation using the fixed effect test, it can be concluded that the Growth Domestic Product (GDP), Inflation (INF), Exchange Rate (EXCH) and Interest Rate (INT) variables have a significant influence on the level of joint-stock index in the 5 ASEAN countries. The probability value is less than alpha (0.05), while the International Reserves (CD), Current account (CA) and the Export-Import (EXIM) variables, with a fixed effect test, showed in no significant effect on the composite stock index in the five ASEAN countries.

Based on the results of the Chow test using Eviews9, the results are as follows: (1) Based on comparison of F-count the F-table; F-count value (4.43) > F-table (2.98), then $\mathrm{H}_{0}$ rejected and Ha accepted, meaning that the model used is the Fixed Effect. (2) Based on the probability of cross-section F with alpha (0.05); A probability value cross-section $\mathrm{F}(0.0000)<$ alpha value $(0.05)$, then $\mathrm{H}_{0}$ rejected and Ha accepted, meaning that the model used is the fixed effect. To determine the influence of the GDP, INF, EXCH and INT against INDEX, panel data regression analysis was performed. The results of using the fixed effect model are shown below.

Table 3. Data Panel Regression Result

\begin{tabular}{|c|c|c|c|c|}
\hline Variable & Coefficient & Std. Error & t-Statistic & Prob. \\
\hline EXCH & 0.478076 & 0.014427 & 33.13804 & 0.0000 \\
\hline PDB & 13.27604 & 3.004526 & 4.418679 & 0.0000 \\
\hline INF & -56.23924 & 6.360746 & -8.841611 & 0.0000 \\
\hline INT & -161.4381 & 17.55164 & -9.197890 & 0.0000 \\
\hline C & 2411.956 & 71.72623 & 33.62725 & 0.0000 \\
\hline
\end{tabular}

Source: Data Processed

Based on the above table it can be obtained panel data regression equation as follows: INDEX $=2411.956+0.478076 \mathrm{EXCH}+13.27604 \mathrm{PDB}-56.23924 \mathrm{INF}-161.4381 \mathrm{INT}$

\section{Conclusion}

This study, using regression analysis of panel data on the stock price index in the ASEAN five countries, with the dependent variable and seven macroeconomic variables as independent variables, aims to determine the relationship and influence of those variables. Through using the Common Effect and Fixed Effect Models, with a panel data regression that is testing chow (chow test), Hausman test (Hausman test), and the LM test (LM test) during the selection stage, it can be said that the calculation of the fixed effect model was considered most appropriate because, based on the probability of cross-section with alpha $\mathrm{F}(0,05)$, a probability value cross-section $\mathrm{F}(0.0000)<$ alpha value $(0.05)$, then $\mathrm{H}_{0}$ rejected and Ha accepted, means that the model used is the fixed effect. Only four macroeconomic variables showed a significant effect. These are GDP, interest rates, exchange rates, and inflation. Meanwhile, three other variables (foreign exchange reserves, current accounts and export and import) did not show a significant effect.

\section{References}

Auzairy, N. A., Ahmad, R., \& Ho, C. S. (2011). Stock Market Deregulation, Macroeconomic Variables and Stock Market Performances. International Journal of Trade, Economics and Finance, 2(6), 495-500

Barakat, M. R., Elgazzar, S. H., \& Hanafy, K. M. (2015). Impact of Macroeconomic Variables on Stock Markets: Evidence from Emerging Markets. International Journal of Economics and Finance, 8(1), 195.

Elite Forex Signal, (2013), Impact of Foreign Reserves on Karachi Stock exchange Market of Pakistan, http://www.eliteforexsignals.com

Fama, E. F., (1981), Stock Returns, Real Activity, Inflation, and Money, The American Economic Review, 71(4), 545565 [Online] Available at: http://www.jstor.org/stable/1806180 
Fahrmeir, L., Kneib, T., Lang, S., \& Marx, B. (2013). Regression Models. In Regression (pp. 21-72). Springer Berlin Heidelberg.

Gültekin, M. N., \& Gultekin, N. B. (1983). Stock Market Seasonality and the Turn of the Tax-year Effect: International Evidence. Salomon Bros. Center for the Study of Financial Institutions, Graduate School of Business Administration, New York University.

Talla, J. T. (2013). Impact of macroeconomic variables on the stock market prices of the Stockholm stock exchange (OMXS30). Jonkoping International Business School.

Kandir, S. Y. (2008). Macroeconomic variables, firm characteristics and stock returns: evidence from Turkey. International research journal of finance and economics, 16(1), 35-45.

Kurihara, Y. (2006). The relationship between exchange rate and stock prices during the quantitative easing policy in Japan. International Journal of Business, 11(4), 375-386

Kwon, C. S., \& Shin, T. S. (1999). Cointegration and causality between macroeconomic variables and stock market returns. Global Finance Journal, 10(1), 71-81.

Naka, A., Mukherjee, T., \& Tufte, D. (1998), Macroeconomic Variables and the Performance of the Indian Stock Market, University of New Orleans, Department of Economics and Finance, Working Papers, [Online] Available at: http://louisdl.louislibraries.org/cgi-bin/showfile.exe?CISOROOT=/ EFW\& CISOPTR=14

Nishat, M. \& Shaheen, R. (2004), Macroeconomic Factors and Pakistani Equity Market, The Pakistan Development Review, 43(4), 619-637

Ologunde, A. O., Elumilade, D. O., \& Asaolu, T. O. (2007). Stock Market Capitalisation and Interest Rate in Nigeria: A Time Series Analysis. Economic and Policy Review, 13(2).

Oseni, I. O., \& Nwosa, P. I. (2011). Stock market volatility and macroeconomic variables volatility in Nigeria: an exponential GARCH Approach. European Journal of Business and Management, 3(12), 43-53.

Ray, S. (2012). Foreign exchange reserve and its impact on stock market capitalization: Evidence from India. Research on Humanities and Social Sciences, 2(2), 46-60.

Saunders, A., \& Tress, R. B. (1981). Inflation and stock market returns: some Australian evidence. Economic Record, 57(1), 58-66.

Widarjono, A. (2010). Analisis statistika multivariat terapan [Applied multivariate statistical analysis]. UPP STIM YKPN, Yogyakarta. 